\title{
An approximate method for estimating water consumption according to tourist land use patterns: evidence from Gandía municipality (Spain)
}

\author{
R. Temes \\ Department of Urban Design and Regional Planning, \\ Polytechnic University of Valencia, Spain
}

\begin{abstract}
This paper is a partial result of the research project, Strategies for Sustainable Regeneration in Tourism Settlements on the Mediterranean Coast (ERAM) of the 2011 National Research Plan of Spain. The research focuses on one of the 68 coastal towns of the Valencian Community Region (CV) representing more than $12.5 \%$ of the GDP. Although tourism is a fundamental economic strategy for many coastal cities, it is one of the main drivers of global environmental change and affects scarce water resources, including those in southern Spain.

This paper concerns a demonstration of the validity of an approximate method to estimate indoor-outdoor water consumption according to tourist land use patterns, and to provide quantitative information on water consumption in gardens and swimming pools as water-related leisure structures. The analysis combines water consumption statistics with population census and "Housing 2011", and uses geo-data based on the SIOSE 2011 project, the CV05 cartography from the Valencian Cartographic Institute and the Spanish homeownership registry. The results show the different tourist consumption due to land-use patterns and the validity of a method to approximate complete measurement of all coastal municipalities in CV.

Keywords: tourism water consumption, sustainable regeneration, touristic destinations, touristic indicators, Valencian community.
\end{abstract}




\section{Introduction}

Along the Spanish coast, on the strip of $500 \mathrm{~m}$, are situated around 500 municipalities, belonging to 23 different provinces of 10 different regions and two autonomous cities. This administrative reality makes the management of the Spanish coast extremely complex, due to the multiple political measures and expectations that are around it. In each one of these regions and autonomous cities, reality is far different as it is the proportion of territory that is part of the strip of 500 meters of coast. According to SIOSE 2009 data (System of Information regarding the Occupancy of the Land in Spain) [1] until today the most disorganized system of geographic information about uses and occupancy of the land done homogeneously for the entire Spanish territory, it is in this littoral strip where the major and most important expansions have been occurring during the last few decades in Spain. Inside the artificial covering of the SIOSE, updated in 2009, the mixed urban land occupies 88,493 ha, where 32,725 are downtown or first expansion areas (ensanche), in other words, continuous land with dense and high construction, and 55,768 are discontinuous land or expansive urbanism. The discontinuous land is an area with a lower density of population than the continuous land, it occupies a larger area and generates higher maintenance costs of infrastructure. The Valencian region has always been characterized as being a territory with middle size cities with a mainly compact urbanism, typical of the European Mediterranean cities. However since the 1990s, a high increase of extensive expansion, mainly on the coastal area, has transformed most of the littoral landscapes and generated important transformations [2].

\subsection{The Valencian touristic model}

Inside this strip of 500 meters the main activities are leisure, tourism, and second residencies, the tourism industry being the one representing, according to the IMPACTUR (2007) [3] report, the $13.2 \%$ of regional GDP, meaning $76 \%$ of the total amount of services exports and $4 \%$ of total investment. However, the Valencian touristic model also has its singularities. Instead of choosing a professional model of touristic production in close relationship with the territory, the Valencian region, as the Murcian region and Andalucía, following real estate interests and inertia of the economy, has configured a touristic model where environment treatment and services are just secondary factors [4, 5].

Without a doubt the touristic leadership of the region comes from the immense unregulated accommodation; more than 2.6 million beds in residential dwellings, with a potential touristic use and discontinuous occupancy that are conditioning how Valencian tourism operates. Inappropriately named "residential tourism", it is one of the most important industries of the Valencian region regarding investments, rent and, most of all, employment. For its part, the legal offering given by hotels and registered littoral apartments, represent a similar number to the existing on the province of Madrid regarding bed numbers, a situation that would be much lower if we do not take into account Benidorm, focus of foreign and local tourism in Western Europe offering integrated and 
competitive touristic services as its Tourism Index shows in 2006-2013: 2733$2944[5,6]$.

Moreover, in a territory not characterized by its abundance in water resources, the consumption of the touristic industry is a first line subject to deal with. As Rico Amorós states [7] an analysis of the units of water consumption associated with the touristic activities is essential to value the environmental and socioeconomic efficiency model of the Valencian urban-touristic territorial development.

\subsection{General objectives and structure of the work}

This paper's main objective is to define an indirect method of evaluation and measurement of water consumption of the touristic offer (official and unregistered) based on a common behavior that will, therefore, permit its application to the 474 kilometers of coast and 21,327 ha of Valencian coast strip.

To do so, it is vital to attend to the different manners of territorial implementation of these activities, especially regarding hotel and residential occupancy, comparing the efficiency of drinking water management in low and high density urban models. This paper follows a line not yet studied by other investigations that have also evaluated the real consumption of touristic spaces $[7,8]$ and takes some data and information from these studies about estimated consumptions of each type of settlement.

The study is based in Gandía, one of the touristic municipalities with the greatest dynamism of the Valencian region. The area of "Playa de Gandía", where this investigation is focused, has 7 kilometers of littoral and an area of 700,000 square meters of fine and white sand. It also has an estimated accommodation infrastructure of 95,000 beds that makes it one of the 5 most visited touristic destinations of the Valencian region (after Benidorm, Valencia, Alicante and Peñiscola).

With this source of geographic framework, the study establishes a comparison between the results of water consumption obtained from measurements and indirect sources (cartography and average estimations of consumption) and data obtained from real consumptions given by the water supply company of Gandía ("Aguas de Valencia").

The methodology applied, therefore, is quantitative with the use of secondary sources that are compared with real measurements. The main secondary sources are the home-ownership registry (Cadaster) from the Spanish Housing Ministry, the cartography CV05 from the Valencian Institute of Cartography, the Population and Housing census of 2011, and the project SIOSE 2011. The graphical representation and the measurements have been done with the ArcGis software (Geographic Information System GIS).

\section{Territorial and chronological frame of reference}

The distribution of tourism demand in the Valencian community highlights that, despite the various diversifying trends of recent times, the Valencian tourism system - from a territorial perspective - lies essentially in the conurbation of the 
littoral structured by large infrastructures such as CN-340, AP-7 from 'Vinaròs' to Valencia and the $\mathrm{CN}-332$ between the regional capital and 'Pilar de la Horadada', that have acted as the main catalysts of the urbanization process.

Inside this littoral structure we find Gandía, a municipality with a population over 75,000 inhabitants, although with a variable population that gives a total of 100,000-120,000 inhabitants. This gives Gandía the condition of the seventh largest city by population numbers and one of the most important of the region, due to its history and also its proximity to the limits of Valencia and Alicante. Furthermore, Gandía is one of the main touristic destinations of Spain, multiplying its population by three, to almost 320,000 residents, during the summer.

Our work focuses attention on the most touristic area of the municipality: Playa de Gandía, with an area of over 226.5 ha and formed by the Census Areas (SC) SC4613104003 and SC4613104005.

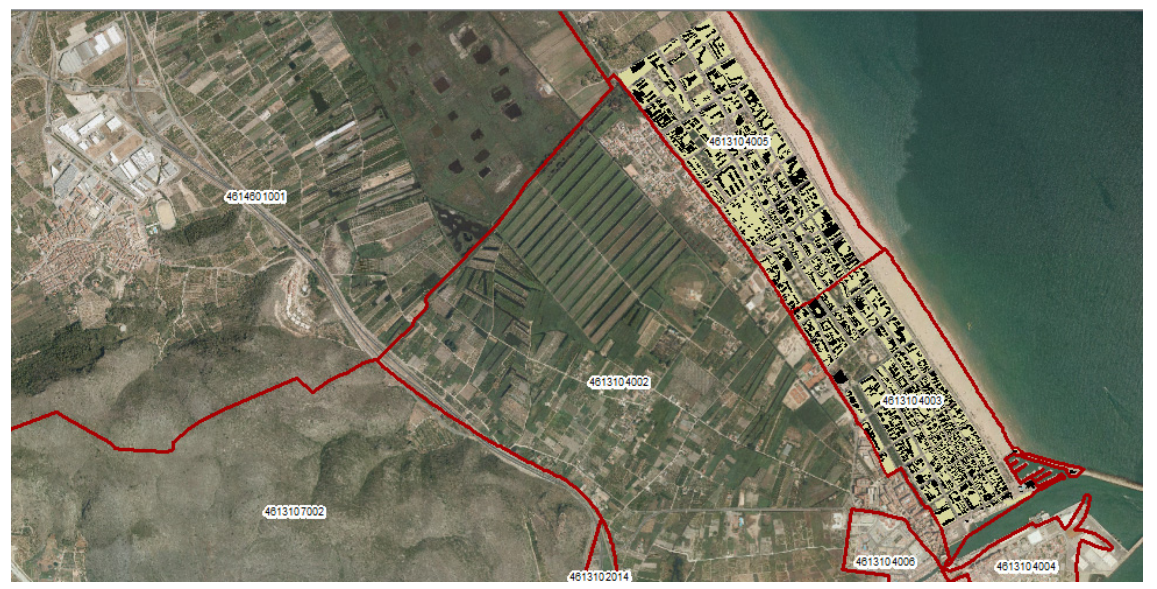

Figure 1: "Playa de Gandía". Census Areas (SC).

To guarantee an adequate homogeneity and coordination for the comparison of data, the year 2011 has been taken as the reference year. Thus the population data as well as the home-ownership data and the measurements of the real consumption given by "Aguas de Valencia" are analyzed for the same period.

\section{Settlement touristic patterns}

In Spain there are no statistical data on the total urban suppliers at a local scale, nor data differentiating the consumption by housing type or buildings related to the touristic and leisure industry. For its part, although there are some public cartographic products of an excellent quality, it is not possible to make an automatic evaluation of the regulated and unregulated tourism from them. Together with these limitations, we should add two more difficulties. On the one hand, although the regulated offering is identified with a common architecture 
typology of the Spanish coast (hotel or apartment-hotel) that is usually present as one or more multifamily buildings, the unregulated offering has a major diversity. We should at least differentiate between the apartments used as multifamily buildings and the single family buildings (Table 1). Also, season, or the grade of intensity of use of accommodation during the year, is another factor to take into consideration when water consumption is estimated, although it affects the regulated offering as well as the unregistered one.

Table 1: Typologies of touristic settlements.

\begin{tabular}{|c|c|c|c|c|c|}
\hline & \multicolumn{4}{|c|}{ Multifamily Buildings } & $\begin{array}{l}\text { Single Family } \\
\text { Buildings }\end{array}$ \\
\hline $\begin{array}{l}\text { Official } \\
\text { tourism }\end{array}$ & Hotel & Hotel-apartment & Hostel & Apartments & - \\
\hline $\begin{array}{l}\text { Unregistered } \\
\text { tourism }\end{array}$ & \multicolumn{4}{|c|}{ Apartments } & Apartments \\
\hline $\begin{array}{c}\text { Residential } \\
\text { dwelling }\end{array}$ & \multicolumn{4}{|c|}{ Housing } & Housing \\
\hline
\end{tabular}

As can be seen in Tables 2 and 3, the studied district is an area where the unregistered offering of touristic spaces prevails over the official sites, mainly due to the existence of apartments in multifamily buildings. If we take percentages, $83 \%$ of the offering is characterized by the unregistered model, $8.7 \%$ by the official tourism concentrated mainly in hotels and hotel-apartments; and $8.3 \%$ by permanent residential occupancy of the area.

Table 2: Distribution of the official and unregistered offerings.

\begin{tabular}{cccc} 
Census & Total & Official tourism* & $\begin{array}{c}\text { Non official tourism**+ } \\
\text { Residential dwelling }\end{array}$ \\
\hline Number & Accommodation & $\mathrm{N}^{\text {o }}$ of rooms & Accommodation \\
\hline Total & $\mathbf{5 0 , 3 3 2}$ & $\mathbf{4 , 7 9 5}$ & $\mathbf{4 5 , 5 3 7}$ \\
SC 4613104003 & 20,322 & 2,739 & 17,583 \\
SC 4613104005 & 30,010 & 2,056 & 27,954 \\
\hline
\end{tabular}

*Hotel, apartments; **Residential dwelling, unregistered tourism, empty dwelling.

Table 3: Detail of the first residence and unregistered offering.

\begin{tabular}{cccc} 
Census & $\begin{array}{c}\text { Residential } \\
\text { dwelling }\end{array}$ & Unregistered tourism & Empty dwelling \\
\hline Number & Accommodation & Accommodation & Accommodation \\
\hline Total & $\mathbf{4 , 5 2 8}$ & $\mathbf{4 4 , 5 1 8}$ & $\mathbf{1 , 0 1 9}$ \\
SC 4613104003 & 2,864 & 16,796 & 786.9 \\
SC 4613104005 & $1,664.1$ & 27,722 & 232.2 \\
\hline
\end{tabular}




\subsection{Method for measurement of tourism uses}

With regard to the different types of tourism uses, we have employed the homeownership cartography to be able to approximate the real use of leisure space. This cartography, with a 1:500 scale, is the most precise one with a national coverage so it is consistent with the systematic method that we propose to use in this study. Although the procedure used allows distinction between single family residences and the multifamily buildings and guarantees the distinction of the land use for hotel and hotel-apartment buildings, it is impossible to distinguish between what we consider residential dwellings and unregistered tourism. To obtain the data, we have used statistical differentiation based on the percentages of residential dwellings and unregistered tourism offered by the Census of Population and Housing 2011. Thanks to these data we have been able to classify the accomodation units from which we will calculate indoors consumptions.

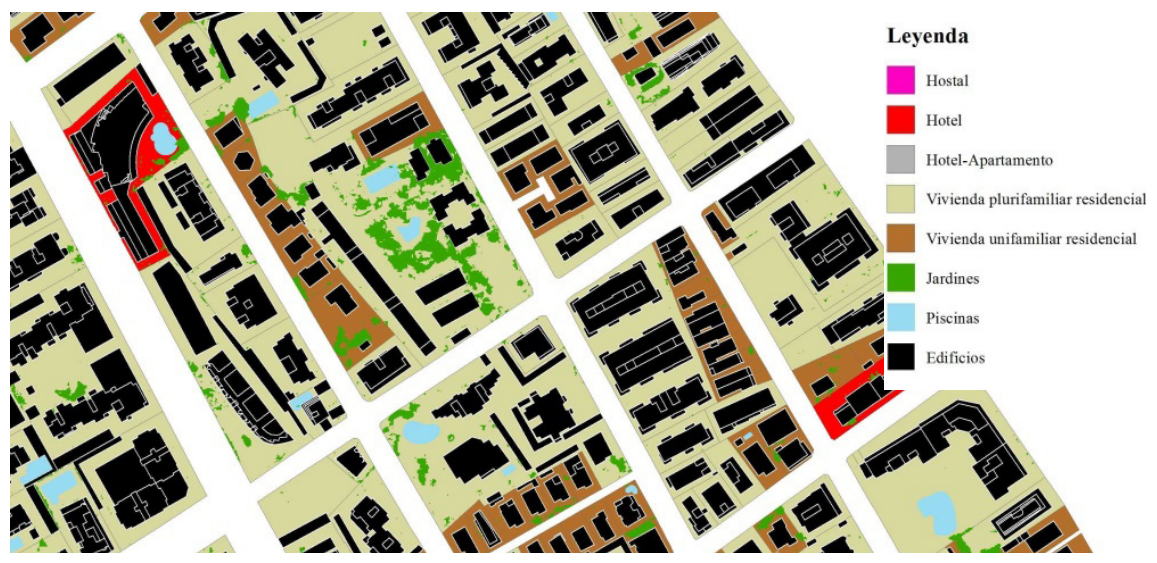

Figure 2: Types of land use according to city planning.

The outdoor consumption measurements have been undertaken by evaluating two types of water consumption - surface irrigation of green areas and filling and maintenance of swimming pools.

For the measurements of the green areas using a systematic method that would be useful afterwards for other coastal municipalities, we have been working on false color IRG or close infrared orthophotos from the Valencian Institute of Cartography. The infrared radiation or IR radiation is a type of electromagnetic and thermal radiation that, thanks to the sensibility of the films used for obtaining these pictures, can be taken. These photographs are sensitive to green, red and infrared, instead of blue, green and red, and therefore the visible colors for the human eyes are modified producing the characteristic colors of these photographs.

Regarding the measurement of the areas used as pools, the procedure has been much easier because the data has been directly obtained from the CV05 
cartography from the Valencian Institute of Cartography that covers the entire region and distinguishes with enough quality the perimeters of three zones.

Table 4: Area outdoors.

\begin{tabular}{cccc} 
Census Tract & Built up area $\left(\mathrm{m}^{2}\right)$ & Pools area $\left(\mathrm{m}^{2}\right)$ & Garden area $\left(\mathrm{m}^{2}\right)$ \\
\hline Number & 790 plots & 281 pools & 612 plots with gardens \\
\hline Total & $\mathbf{1 , 1 2 4 , 2 4 0}$ & $\mathbf{3 8 , 0 0 6}$ & $\mathbf{1 4 0 , 3 7 0}$ \\
SC 4613104003 & 506,758 & 17,119 & 42,963 \\
SC 4613104005 & 617,482 & 20,887 & 97,407 \\
\hline
\end{tabular}

\section{Estimation of population and water consumption indoors and outdoors}

The estimation of population as well as the consumption of water in the touristic area requires precise explanation, because there are different options to evaluate the figures. In both cases, the approximation undertaken has been based on the report by Hof and Schmitt [8].

\subsection{Estimation of population and year}

We have selected two possible scenarios of tourism impact on the area. First, a calculation of the official population which represents minimum population (Table 5):

Table 5: Official population.

\begin{tabular}{ccccc} 
Census tract & $\begin{array}{c}\text { Census } \\
\text { population } \\
2011\end{array}$ & $\begin{array}{c}\text { Hotel } \\
\text { seats }\end{array}$ & $\begin{array}{c}\text { Monthly capacity } \\
\text { utilization factor } \\
\text { (Hotels) }\end{array}$ & $\begin{array}{c}\text { Official } \\
\text { population }\end{array}$ \\
\hline Number & Inhabitants & $\begin{array}{c}\text { Number } \\
\text { of beds }\end{array}$ & \\
\hline Total & $\mathbf{5 , 4 0 3}$ & $\mathbf{4 , 7 9 5}$ & & $\mathbf{8 , 0 6 4}$ \\
SC 4613104003 & 3,221 & 2,739 & $\mathbf{5 5 . 4 9}$ & 3,221 \\
SC 4613104005 & 2,182 & 2,056 & & 2,182 \\
\hline
\end{tabular}

Official population $=$ official census data $+($ (hotel beds + apartments beds $) \times($ monthly capacity utilization factor)).

Second, a calculation where the potential population represents a maximum, reflecting the maximum residential population plus tourists in second homes and in non-declared units (Table 6): 
Table 6: Potential population.

\begin{tabular}{ccccc} 
Census tract & $\begin{array}{c}\text { Unregistered } \\
\text { tourism* }\end{array}$ & $\begin{array}{c}\text { Hotel } \\
\text { accommodation }\end{array}$ & $\begin{array}{c}\text { Monthly capacity } \\
\text { utilization factor } \\
\text { (Hotels) }\end{array}$ & $\begin{array}{c}\text { Potential } \\
\text { population }\end{array}$ \\
\hline Number & Accommodation & Number of beds & & \\
\hline Total & $\mathbf{4 4 , 8 2 8}$ & $\mathbf{4 , 7 9 5}$ & $\mathbf{4 4 , 8 2 8}$ \\
SC 4613104003 & 20,880 & 2,739 & 55.49 & 20,880 \\
SC 4613104005 & 23,948 & 2,056 & 23,948 \\
\hline $\begin{array}{l}\text { Potential population }=((\text { no. of apartments }+ \text { no. of flats }+ \text { no. of single residential houses }) \times \\
\text { (average household size) }+(\text { (hotel beds }+ \text { apartments beds }) \times(\text { monthly capacity utilization factor) }) .\end{array}$ \\
*(no. of apartments + no. of flats + no. of single residential houses $) \times$ average household size.
\end{tabular}

The average household size is 2.58 persons according to INE (2013) and the capacity utilization factor includes monthly percentage of open hotels and tourist apartments and their utilization factor according to "Encuesta de ocupación Hotelera (2011)" [9]. The resulting water consumption figures are compared with findings from other studies in similar climates and contexts $[7,10]$.

\subsection{Estimation of indoor, outdoor and per capita water consumption for different of domestic water uses}

As the Hof and Schmitt report mentions [8], other studies in similar climates and contexts have shown that analyses of domestic water consumption have to take three variables into account for explaining model patterns: per capita consumption indoors (dependent on household size, seasonality of inhabitancy and capacity utilization of tourist accommodation), and outdoor water consumption for garden irrigation and swimming pool maintenance [11, 12].

The following sections outline the methodology to determine each of the variables for domestic water consumption analysis.

\subsubsection{Indoor water consumption: official tourist accommodation in hotels, hotel-apartments and hostels}

In Table 2 we summarize the data related to the number of hotel beds in the studied area. We already know that water consumption is directly related to the hotel category [11]. Taking the previous report as a guide, we can use an average monthly consumption, depending on the category, the ones shown in Table 7, and calculate the monthly indoor consumption of the official tourist offering.

\subsubsection{Indoor water consumption: official tourism and unregistered tourism in multifamily and single family buildings}

Similar to the previous case in Table 2, we summarize the data related to the number of "No official tourism" existing in the studied area. Based on the RicoAmoros et al. work [11], we can estimate the consumption per inhabitant and day depending on the type of settlement and calculate the indoors monthly consumption of the unregistered tourism offer in: 
Table 7: Water consumption in hotels according to category.

\begin{tabular}{cccccc}
$\begin{array}{c}\text { Hotel } \\
\text { category }\end{array}$ & $\begin{array}{c}\text { Census tract } \\
\text { (Number of beds) }\end{array}$ & $\begin{array}{c}\text { Average } \\
\text { consumption } \\
\text { per bed } \\
\text { occupied } \\
(1 / \mathrm{p} / \mathrm{d})^{*}\end{array}$ & $\begin{array}{c}\text { Monthly capacity } \\
\text { utilization factor } \\
(\text { Hotels })\end{array}$ & $\begin{array}{c}\text { Water } \\
\text { consumption } \\
\text { per month } \\
\left(\mathrm{m}^{3}\right)\end{array}$ \\
\hline Total & SC 4613104003 & SC 4613104005 & & & $\mathbf{2 4 , 1 8 2 . 3}$ \\
\hline 1 Star & 158 & - & 174 & & 453.62 \\
2 Star & 32 & - & 194 & 55,49 & 102.43 \\
3 Star & 1,059 & 2,056 & 287 & & $14,751.08$ \\
4 Star & 1,490 & - & 361 & & $8,875.19$ \\
\hline
\end{tabular}

*Source: Rico-Amoros et al. [11].

Table 8: Water consumption in unregistered tourism.

\begin{tabular}{ccccc} 
& $\begin{array}{c}\text { Capacity of accommodation per } \\
\text { Census tract }\end{array}$ & $\begin{array}{c}\text { Av. C } \\
(1 / \mathrm{p} / \mathrm{d})^{*}\end{array}$ & $\begin{array}{c}\text { Water consumption } \\
\text { per month }\left(\mathrm{m}^{3}\right)\end{array}$ \\
\hline Type & SC 4613104003 & SC 4613104005 & & $105,234.83$ \\
\hline $\begin{array}{c}\text { Multifamily } \\
\text { apartments }\end{array}$ & 7,755 & 9,021 & 142 & $101,409.91$ \\
\cline { 1 - 2 } $\begin{array}{c}\text { Single family } \\
\text { apartments }\end{array}$ & 338 & 261 & 150 & $3,824.91$ \\
\hline
\end{tabular}

*Source: Rico-Amoros et al. [11]. Average consumption per seat occupied (1/p/d).

\subsubsection{Outdoor water consumption: pools}

To estimate pool water consumption, evaporation will be taken into account by square meter of pool area and filling. In this case we have followed the estimations made by Hof and Schmitt [8]:

$$
\mathrm{W}_{\text {Pool }}=\dot{\mathrm{n}}_{\text {average }} * \mathrm{a}_{\text {Pool }} * \text { days }+ \text { a }_{\text {Pool }} * \text { average pool depth } * 1000 / 12
$$

where WPool: sum of pool water evaporation loss and filling of pool (litres per

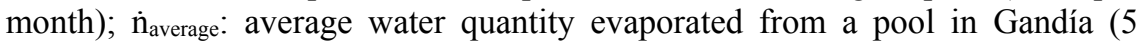
liters per square meter per day); apool: pool area (square meters); average pool depth: 1.5 meter.

Table 9: Water consumption in pools.

\begin{tabular}{ccc} 
Census tract & Pool area $\left(\mathrm{m}^{2}\right)$ & W Pool per month $\left(\mathrm{m}^{3}\right)$ \\
\hline Number & 281 pools & \\
\hline Total & $\mathbf{3 8 , 0 0 6}$ & $\mathbf{1 0 , 4 5 2}$ \\
\hline SC 4613104003 & 17,119 & 4,708 \\
SC 4613104005 & 20,887 & 5,744 \\
\hline
\end{tabular}




\subsubsection{Outdoor water consumption: garden irrigations}

Water availability for garden irrigation has been established following the references present [12]. In this case it is a study undertaken for irrigation systems of private gardens in suburban Barcelona, although we have considered wider intervals of the approximation, because the climate is much dryer in Gandía. With this information, we will take as a reference value: $121 / \mathrm{m}^{2} /$ week. Doing so the results obtained are shown in Table 10:

Table 10: Water consumption in gardening.

\begin{tabular}{ccc} 
Census tract & Garden area $\left(\mathrm{m}^{2}\right)$ & W Pool per month $\left(\mathrm{m}^{3}\right)$ \\
\hline Number & 612 plots with gardens \\
\hline Total & $\mathbf{1 4 0 , 3 7 0}$ & $\mathbf{6 , 7 3 8}$ \\
SC 4613104003 & 42,963 & 2,062 \\
SC 4613104005 & 97,407 & 4,676 \\
\hline
\end{tabular}

\section{Conclusions}

The objective of this study is to establish a systematic method applicable to the Valencian touristic coast that would allow the estimation of indoor and outdoor water consumption. Table 11 compares values of estimated and real measurements.

Table 11: Water consumption comparisons.

\begin{tabular}{|c|c|c|c|c|c|}
\hline & $\begin{array}{l}\mathrm{W}_{\mathrm{G}} \\
\mathrm{p} / \mathrm{m} \\
\left(\mathrm{m}^{3}\right)\end{array}$ & $\begin{array}{l}\mathrm{W}_{\mathrm{P}} \\
\mathrm{p} / \mathrm{m} \\
\left(\mathrm{m}^{3}\right)\end{array}$ & $\begin{array}{c}\mathrm{W}_{\mathrm{C}} \\
\text { Unregistered } \\
\text { tourism }\left(\mathrm{m}^{3}\right)\end{array}$ & $\begin{array}{l}\mathrm{W}_{\mathrm{C}} \text { official } \\
\text { tourism }\left(\mathrm{m}^{3}\right)\end{array}$ & $\begin{array}{l}\mathrm{T}_{\mathrm{Tw}} \\
\mathrm{p} / \mathrm{m} \\
\left(\mathrm{m}^{3}\right)\end{array}$ \\
\hline Total & 10,985 & 10,452 & 105,235 & 24,182 & 150,854 \\
\hline SC 4613104003 & 3,362 & 4,708 & 49,037 & 14,446 & 71,553 \\
\hline SC 4613104005 & 7,623 & 5,744 & 56,198 & 9,736 & 79,301 \\
\hline & \multicolumn{2}{|c|}{$\begin{array}{c}\text { EWC }_{\mathrm{WC}} \\
\mathrm{p} / \mathrm{m}\left(\mathrm{m}^{3}\right)\end{array}$} & $\begin{array}{c}R_{W C} \\
\mathrm{p} / \mathrm{m}\left(\mathrm{m}^{3}\right)\end{array}$ & $\begin{array}{c}\text { Difference } \\
\left(\mathrm{m}^{3}\right)\end{array}$ & $\%$ \\
\hline Total & \multicolumn{2}{|c|}{150,854} & 178,697 & $-27,843.02$ & -15.58 \\
\hline SC 4613104003 & \multicolumn{2}{|c|}{71,553} & & & \\
\hline SC 4613104005 & \multicolumn{2}{|c|}{79,301} & & & \\
\hline
\end{tabular}

As a conclusion to our work we will highlight some ideas:

- The method considered, when compared with real measurements, gives a $16 \%$ error. It can be considered acceptable because it is caused by the following factors:

- The real measurements $\left(\mathrm{R}_{\mathrm{WC}}\right)$ given by the firm "Aguas de Valencia" $\left(2,144,368 \mathrm{~m}^{3} /\right.$ year in 2011) warns about the impossibility of filtering the data of industrial and commercial consumption. Therefore we start 
from the basis that the measurements we have used are higher than the values we wish to estimate.

- On the other hand, the estimated measurement $\left(E_{W C}\right)$ works with monthly average use in apartments and hotels. If this estimation was done for the period of a year using monthly data, the result would be more adjusted.

- We have detected some errors on the identification of unregistered tourism in the home-ownership data used in the study. These errors give a lower number of beds than existing in the area. Thus, a correction of home-ownership data would improve the results.

- The identification using false IRG color or close infrared orthophotos, although it is a quick way to count surfaces, requires an important adjustment. In areas where there are reflected shadows, green areas are not detected.

- As additional improvements, a validation should be done based on several municipalities to prove that the deflection obtained is homogeneous, or that there are different local deflections.

This report is a first step supported by specialized references in the path to achieve a better and more effective control of water consumption in large regions such as the $\mathrm{CV}$.

\section{References}

[1] Tena, J. C. M., Cartografía del urbanísmo expansivo valenciano según SIOSE. Geografía y desafíos territoriales en el siglo XXI. Ed. Asociación de Geógrafos Españoles, Madrid, pp. 415-426, 2011.

[2] Temes R. \& Giménez E. The urban region of Valencia: a territory undergoing profound transformation. (Chapter 2). The explosion of the city: territorial transformations in the South Europe urban regions. ed. A. Font, Ministerio de Vivienda, Madrid, pp. 312-327, 2007.

[3] EXCELTUR, Estudio del Impacto económico del turismo sobre la economía y el empleo de la Comunitat Valenciana 2007. IMPACTUR, Generalitat Valenciana, 2008.

[4] Miralles, J. L., \& García-Ayllón, S. The economic sustainability in urban planning: case La Manga. WIT Transactions on Ecology and the Environment, 173, pp. 279-290, 2013.

[5] Obiol, E. \& Pitarch, M., El litoral turístico valenciano: intereses y controversias en un territorio tensionado por el residencialismo. Boletín de la Asociación de Geógrafos Españoles, 56, pp. 177-200, 2011.

[6] CAIXA, Anuario económicode España 2007, www.laCaixa.es/estudios.

[7] Rico Amorós, A. M., Tipologías de consumo de agua en abastecimientos urbano-turísticos de la Comunidad Valenciana. Investigaciones Geográficas, nº42, pp. 5-34, 2007.

[8] Hof, A., \& Schmitt, T., Urban and tourist land use patterns and water consumption: Evidence from Mallorca, Balearic Islands. Land Use Policy, 28(4), pp. 792-804, 2011. 
96 Ecosystems and Sustainable Development X

[9] INE, Encuesta de la ocupación hotelera, http://www.ine.es/jaxi/menu.do? type $=$ pcaxis \&path $=\% 2 \mathrm{Ft} 11 \% 2 \mathrm{Fe} 162 \mathrm{eoh} \&$ file $=$ inebase.

[10] Domene, E. \& Sauri, D., Urbanisation and water consumption: influencing factors in the metropolitan region of Barcelona. Urban Stud. 43, pp. 16051623, 2006.

[11] Rico-Amoros, A. M., Olcina-Cantos, J., \& Sauri, D., Tourist land use patterns and water demand: evidence from the Western Mediterranean. Land Use Policy, 26(2), pp. 493-501, 2009.

[12] Domene, E. \& Sauri, D., Modelos urbanos y consumo de agua. el riego de jardines privados en la región metropolitana de Barcelona. Investigaciones Geográficas, 32, pp. 5-17, 2003. 